\title{
ALTERNATION USING BACTERIAL SUPERNATANTS IN DATE PALM MICROPROPAGATION
}

Farrag, Hala M.A.*; Wedad, E. Eweda, ${ }^{* *}, A$. A. Guirgis***; A. M. Ibrahim***; A.A.El-Banna *and I.A. Ibrahim *** ${ }^{*}$ Central Laboratory For Date Palm Res. and Development,Agric. Res. Center (ARC).

**Depart. of Agric. Microbiology, Faculty of Agric., Ain Shams Univ. *** Genetic Engineering and Biotechnology Res.Inst.(GEBRI), Menofyia Univ.

\begin{abstract}
The present investigation was aimed to use phytohormones produced by some bacterial strains like Azospirillum brasilense, Azotobacter chroococcum, Bacillus megaterium and Klebsiella pneumoniae instead artificial hormones as a protocol in date palm micropropagation through somatic embryogenesis induced from shoot tip or leaf primordial explants, which were isolated from offshoot apex. In order to test the possibility to use supernatant of the strains, which are auxin over producers andlor cytokinin over producers in culture medium composition according to development stages for maximizing yield and to study the effect on each stage, i.e., callus initiation, embryo formation, shooting and rooting stages. In general, results showed that Klebsiella and Azotobacter have an auxin effect but Azospirillum and Bacillus were more related to cytokinin nature.
\end{abstract}

\section{INTRODUCTION}

Several soil microorganisms are capable of producing physiologically active quantities of plant growth regulators (PGRs), which may have a pronounced effect on plant growth and development. A diverse array of bacteria, including species of Azospirillum, Azotobacter, Bacillus and Klebsiella have mechanisms by which these rhizobacteria enhance plant growth through producing substances such as auxins, GA3 and cytokinins ( phytohormones) and mineralize organic phosphorus and enhance minerals uptake (Grayston et al. 1990 and Joo et al. 2004). So that, using these natural substances in vitro in culturing economic plants become necessary to overcome increasing artificial substances and that is of variable dangerous on healthy.

Because, date palm is the most important fruit crop planted and as ornamental plants in the Middle East and Arabian lands (FAO, 1984 and Moursy and Saker, 1996). Date palm is a monocot and dioecious fruit tree, which are difficult to study due to their long life. Therefore, in vitro techniques appear to be promising tools to study palm growth and development compared to field and greenhouse experimentation (Tisserat, 1983).

The concentration and type of hormones especially, auxins and cytokinins are considered the most critical factors in stimulating callus production and subsequent embryogenesis (Reynolds and Murashige, 1979 and Tisserat, 1979).

Generally, Auxins play a role in many development processes, including cell elongation, swelling of tissue, apical dominance, adventitious root formation and somatic embryogenesis (Trigiano and Gray, 2000). In 
Farrag, Hala, M.A. et al.

addition, cytokinins are required for inducing cell division, callus formation, cell extension, shoot proliferation and shoot morphogenesis (Pan and Van Staden, 1998) Naphthaleneacetic acid (NAA) and kinetin at levels from 1-10 $\mathrm{mg} / \mathrm{L}$ induced callus growth (Khan et al., 1983). An embryo can be defined as the earliest recognizable multicellular stage of an individual that occurs before it has developed the structures or organs characteristic of a given species (Trigiano and Gray, 2000). Somatic embryogenesis is a process by which somatic (non-gametic) cells undergo differentiation to form a bipolar structure containing both root and shoot axes. These somatic embryos are similar to zygotic embryos and can mature and germinate (Smith, 2000).

Abdel-Hamid et al. (2001) found that in date palm micropropagation, the highest rate of shoot multiplication induced from shoot tip explants was obtained through callus cultured on medium containing $3 \mathrm{mg} / \mathrm{L}$ 2iP. Also, Zaid (2003) showed that in date palm micropropagation that its culture medium was supplemented with $0.5 \mathrm{mg} / \mathrm{L}$ kinetin was more effective than that supplemented with $0.5 \mathrm{mg} / \mathrm{L} 2 \mathrm{iP}$ on stimulating the produced shoots number and shoot length.

\section{MATERIALS AND METHODS}

This work was carried out in the Central Laboratory for Research and Development of Date Palm, Agricultural Research Center (ARC), Ministry of Agriculture, Giza, Egypt and Plant Biotechnology Department, Genetic Engineering and Biotechnology Research Institute (GEBRI), Minufiya University during the period 2003-2006.

\section{Source of bacterial strains:}

Representative bacterial strains used throughout this study were Klebsiella pneumoniae and Azospirillium brasilense ,which were isolated through a previous study carried out at the Environmental Studies and Research Unit (ESRU) Department of Agricultural Microbiology, Faculty of Agriculture, Cairo University, Giza by Farrag(2000). The other two strains Bacillus megaterium and Azotobacter chrooccum were kindly obtained from the Culture Collection of Microbiological Resource Center, Faculty of Agriculture, Ain Shams University, Cairo, Egypt.

\section{Purification and maintenance of the isolates:}

The selected strains were purified by streaking on agar plates containing the proper selective medium for each bacterium type as the following:

I. Nitrogen deficient medium (NFDM) for Klebsiella (Dixon et al., 1980)

II. Semi-solid malate medium for Azospirillium (Dobereiner and Day 1976) III. Nitrogen - deficient medium of Ashby for Azotobacter (Hegazi and Niemela, 1976)

IV. Bacillus medium (Allen, 1959).

which were surface inoculated with single strain and incubated at $28 \pm 2^{\circ} \mathrm{C}$ for $48 \mathrm{hr}$ to 7 days (5-7 times or more) until pure colonies were obtained.

Characteristics of colonies for each tested strains developed on agar plates of every culture medium were carefully examined, which was having different colors. 
Maintenance of the selected strains was carried out by sub-culturing on several selective agar media as slants periodically, which were then kept in refrigerator at $\left(4^{\circ} \mathrm{C}\right)$. Strains were separately grown in liquid medium for preparation batch cultures by inoculating $10 \mathrm{~mL}$ of $10^{5}-10^{6}$ cells $\mathrm{mL}^{-1}$ in selective culture media and incubated in a rotary shaker at $100 \mathrm{rpm}$ and temperature was controlled at $30^{\circ} \mathrm{C}$ to reach a population density of $>10^{7} \mathrm{cfu}$ $\mathrm{mL}^{-1}$ (colony forming/ unit). PH was adjusted to 7.0.

Plant material:

Selected young offshoots, 2-3 years old, were grown in El- Wahaat El- Baharia in Egypt. Offshoots were carefully separated from the mother date palm trees (phoenix dactylifera cv. Sewi). The selected offshoots were $6-9 \mathrm{Kg}$ in weight, about $1-1.5 \mathrm{~m}$ in length and $20-30 \mathrm{~cm}$ in diameter.

Isolation and sterilization of explants:

The selected young offshoots were immediately transferred to the laboratory. Two types of explants were separated from the offshoots, i.e., shoot tip and leaf primordial. For excising both types of explants, the green leaves of the offshoots were carefully removed by using sharp knife. The separation of leaves was carried out starting from the base and acropetaly continued upwards until the white soft leaves, surrounding the shoot tip appeared. However, cork and other remaining tissues of the offshoot were discarded.

The plant materials including the shoot tip region $(10-12 \mathrm{~cm}$ in length and $5 \mathrm{~cm}$ in diameter) were sterilized as follows:

Plant materials were washed several times with liquid soup and water, then placed under running tap water for 2 hours. The plant materials were then surface sterilized by soaking for $3 \mathrm{~min}$ in ethyl alcohol (70\%).

Again, plant materials were surface sterilized by immersing in mercuric chloride solution ( $0.1 \%$ ) containing two drops of tween 20 for 5 min. After removing all affected tissues, the remaining part was sterilized by soaking for $20 \mathrm{~min}$ in commercial Clorox $70 \%(\mathrm{v} / \mathrm{v})$ (sodium hypochlorite $5.25 \%$ ) containing two drops of tween 20 as a surfactant. It was then rinsed three times with sterilized distilled water. Additional injured leaves were removed from the shoot tip material. The shoot tip material was again rinsed with sterilized distilled water and soaked for $20 \mathrm{~min}$. in filter sterilized solutions consisted of citric acid (150 mg/L) and ascorbic acid $(100 \mathrm{mg} / \mathrm{L})$ as an anti-oxidant. The shoot tip materials were again soaked for $20 \mathrm{~min}$. in clorox $50 \%(\mathrm{v} / \mathrm{v})$ (sodium hypochlorite $5.25 \%$ ) containing two drops of tween 20.

Under aseptic conditions, all affected primordial leaves were removed and shoot tip materials were again rinsed three times with autoclaved distilled water followed by soaking in filter sterilized solution containing citric acid (150 mg/L) and ascorbic acid (100 mg/L).

The shoot tip regions including the shoot apex plus the associated primordial leaves were used. Shoot apical meristem plus few primordial leaves (4-5 leaves) were excised together, and would be considered as shoot tip explant. The shoot tip explants was about $1 \mathrm{~cm}$ in length and $0.5-0.8 \mathrm{~cm}$ in diameter. The shoot tip was divided longitudinally with a sharp cuter into 4 
Farrag, Hala, M.A. et al.

equal quarters. The leaf primordial explants were taken from the rest primordial leaves surrounding the meristem tip.

\section{Culture medium:}

The MS basal medium containing macro and microelements as well as vitamins (Murashige and Skoog, 1962) was used in this study.

The control MS basal medium was supplemented with $200 \mathrm{mg} / \mathrm{L}$ glutamine $100 \mathrm{mg} / \mathrm{L}$ myo- inositol, $3 \%$ sucrose and $0.6 \%$ agar. Medium was adjusted to $\mathrm{pH} 5.8 \pm 0.1$.

The medium was distributed into the culture jars $(250 \mathrm{~mL})$; each jar contains $25 \mathrm{ml}$ of MS medium. Jars were capped with polypropylene closure and autoclaved at $121^{\circ} \mathrm{C}$ and $1.1 \mathrm{~kg} / \mathrm{cm}^{2}$ for 20 minutes. The jars were transferred to the culture cabinet to get cool. The different explants were cultured into MS medium supplemented with bacterial supernatants to obtain cultured medium containing all components as natural medium to study its effect on the yield of each studied stage.

\section{Callus initiation stage:}

Twenty-five offshoots were considered as a source of explants. The control medium was MS culture medium $10 \mathrm{mg} / \mathrm{L}, 2,4-\mathrm{D} 3 \mathrm{mg} / \mathrm{L}$ 2iP,30 g/L sucrose and all B. Ss (bacterial supernatants) were added to the MS medium without growth regulators at $150 \mathrm{~mL} / \mathrm{L}$ concentration as recommended by Farrag (2000) in treatments A, a, B, b, C, c and D, d as the following:

A) Azotobacter chrooccum + tryptophane (as a producer for $41 \mu \mathrm{g} / \mathrm{mLGA3} \rightarrow$ $6.2 \mathrm{ML} / 150 \mathrm{~mL}$ ),

a) Azoto. Cultured in free trypto. Medium (non significant production),

B)Klebsiella pneumoniae + tryptophane (IAA over producer $47 \mu \mathrm{g} / \mathrm{mL} \rightarrow 7 \mathrm{~mL} / 150 \mathrm{~mL}$, also GA3 $66 \mu \mathrm{g} / \mathrm{mL} \rightarrow 10 \mathrm{~mL} / 150 \mathrm{~mL}$ ),

b) Kleb. Cultured in free trypto. Medium (non significant production),

C) Azospirillium brasilense + tryptophane ( cytokinin over producer $5.4 \mu \mathrm{g} / \mathrm{mL} \rightarrow 0.81 \mathrm{~mL} / 150 \mathrm{~mL}$ ),

c) Azosp. Cultured in free trypto. medium (non significant production),

D) Bacillus megaterium + tryptophane (non significant production),

d) B. megaterium Cultured in free trypto. medium ( cytokinin producer $5 \mu \mathrm{g} / \mathrm{mL} \rightarrow 0.75 \mathrm{~mL} / 150 \mathrm{~mL}$ ),

These bacterial strains ascertained in the considered treatments were chosen according to their ability to produce phytohormones from previous studies of Farrag et. al. (2007). According to Zaid and Tisserat (1983) cultures were transferred to fresh media every 6 weeks, and incubated in complete darkness for 24 weeks.

The data recorded as follows:

1. Callus formation degree.

2. Browning degree.

3. Swelling degree at the end of each subculture (4 subculture).

The compact callus, which formed from the previous culture were placed on media containing $10 \mathrm{mg} / \mathrm{L} \mathrm{2,4-D}$ and $3 \mathrm{mg} / \mathrm{L}$ 2iP to produced friable callus (control). Data were calculated visually as scores (Pottino, 1981) from $1-4$ as the following:

Negative results $(-) \quad=1$

Below average results $(+) \quad=2$ 
Average results $(++) \quad=3$

Good results $(+++) \quad=4$

Friable callus was transferred to the following media:

$M S+$ free growth regulators (control) was (0).

MS $+150 \mathrm{~mL} / \mathrm{L}$ B.Ss. A, a, B, b, C, c and D, d.

For embryogenesis, each treatment consisted of 3 replicates and each replicate contains about $1 \times 1 \mathrm{~cm}$ friable callus. Cultures were incubated in total darkness for 3 months. Data were recorded as growth vigor and number of embryo.

\section{Shoot formation stage:}

Individual embryos were separated from previous stage and cultured on the same media. The data of growth and development were recorded as:

1. Number of shoots / plant.

2. Shoot length $(\mathrm{cm})$.

3. Growth vigor.

\section{: Root formation stage}

Individual shoots were used as explants in this stage and they were cultured in MS supplemented with NAA (control) $0.1 \mathrm{mg} / \mathrm{L}$ and the same treatments. All culture media of each treatment were distributed into culture tubes. The culture tubes were generally placed in light condition for $16 \mathrm{~h}$ illumination of 3000 lux light intensity (white fluorescent tubes) at $27 \pm 2^{\circ} \mathrm{C}$.

The data of this stage were recorded as:

1. Number of roots/ plant.

2. Root length $(\mathrm{cm})$.

3. Growth vigor.

Statistical analysis:

Experiments were arranged in factorial complete design and date were statistically analyzed according to method described by Snedecor and Cochoran (1972).

\section{RESULTS AND DISCUSSION}

\section{callus initiation:}

Data presented in Table (1) showed callus formation, browning and swelling degree as affected by adding bacterial supernatants. Results revealed that the highest score value of callus formation degree was observed with Klebsiella supernatant in the presence of tryptophan (B) that is $(r, 0)$ followed by Azotobacter supernatant $(A)$, Azospirillium supernatant $(C)$ with tryptophan and control(0), which recorded the same score (3). These treatments were the best in the swelling (3.25) except for the control (2.25). On the other hand, treatment $(\mathrm{C})$ was the lowest in the browning degree (0.5), in the opposite, the highest value of browning degree was (2.5) in (A) and (D) treatments but the lowest values of callus degree was in Azospirillium supernatant free tryptophan (c) and Bacillus supernatant free tryptophan (d) which their score were (1) . In this respect, Chung and Tzeng (2004) showed that the production of IAA in culture media was solely dependent on the presence of tryptophan. Moreover, One et al. (2005) stated 
that varying the concentration of tryptophan in batch experiments has an effect on both growth of Azospirillum and IAA synthesis. This results are in agreement with the obtained results which, in the present study, which gave positive effect by using bacterial supernatants from medium containing tryptophan as precursor for production of auxin.

Table(1) . Effect of bacterial supernatant added to MS medium on callus development and differentiation of date palm(Phoenix dactylifera cv.Sewi) after 18 weeks from culturing

\begin{tabular}{|l|c|c|}
\hline Treatments & Growth vigor & Number of embryo \\
\hline Azotobacter chrooccum (A) & 3.0 & 15 \\
\hline Azoto. free tryptophan (a) & 2.5 & 10 \\
\hline Klebsiella pneumoniae (B) & 3.5 & 20 \\
\hline Klebsiella free tryptophan (b) & 1.5 & 6.0 \\
\hline Azospirillium brasilense (C) & 4.0 & 30 \\
\hline Azosp. free tryptophan (c) & 3.0 & 17 \\
\hline Bacillus megaterium (D) & 3.5 & 26 \\
\hline Bacillus free tryptophan (d) & 4.0 & 25 \\
\hline Control & 3.0 & 18 \\
\hline L.S.D. at 5\% & 1.01 & 4.4 \\
\hline
\end{tabular}

Moreover, Reuveni and Kipnis (1974) showed that auxins were found to be the most critical component in the media for callus production and Tisserat (1982) mentioned that (MS) medium supplemented with high level of auxin resulted in high percentage of callus. In this concern, Brackpool (1988) reported that in date palms micropropagation, high concentrations of the artificial auxins naphthaleneacetic acid (NAA) and 2,4-dichlorophenoxyacetic acid (2,4-D) are needed to induce callus formation. While (Trigiano and Gray 2000) reported that auxins play a role in many development processes, including cell elongation, swelling of tissue, apical dominance, adventitious root formation and somatic embryogenesis.

\section{Embryogenesis:}

The effect of bacterial supernatants on callus development is shown in Table (2). Results revealed that the greatest number of individual embryos was (30) in MS medium supplemented with Azospirillium supernatant with tryptophan (C) followed by (26) formed by using Bacillus supernatant with tryptophan (D)and (25) in Bacillus supernatant from medium free tryptophan (d) this results may due to the presence of cytokinin in this supernatants. In addition, the best growth vigor was due to (C) and (d) which recorded a score (4) that may be owed to presence other substances like gibberellins and auxins. These results are in harmony with Gonzalez - Lopez et al., (1986) who observed that the culture supernatant of $A$. chroococcum \& $A$. vinelandii contained at least three gibberellins-like substances. Mahmoud et al. (1984) investigated the ability of different isolates belonging to genera Bacillus and Azotobacter to synthesize plant growth substances. The supernatant of the bacterial cultures showed the presence 
of a compound, which correspond to indole acetic acid together with unidentified derivatives. These organisms also secreted gibberellins.

Table(2) . Effect of bacterial supernatant on callus formation of date palm(Phoenix dactylifera cv.Sewi) after 18 weeks from culturing (three subculture)

\begin{tabular}{|l|c|c|c|}
\hline Treatments & $\begin{array}{c}\text { Callus } \\
\text { Formation }\end{array}$ & Browning & Swelling \\
\hline Azotobacter chrooccum (A) & 3.0 & 2.5 & 3.25 \\
\hline Azoto. free tryptophan (a) & 2.0 & 1.5 & 2.0 \\
\hline Klebsiella pneumoniae (B) & 3.5 & 1.0 & 3.25 \\
\hline Klebsiella free tryptophan (b) & 1.5 & 1.0 & 1.25 \\
\hline Azospirillium brasilense (C) & 3.0 & 0.5 & 3.0 \\
\hline Azosp. free tryptophan (c) & 1.0 & 1.0 & 2.0 \\
\hline Bacillus megaterium (D) & 2.5 & 2.5 & 3.25 \\
\hline Bacillus free tryptophan (d) & 1.0 & 2.0 & 2.25 \\
\hline Control & 3.0 & 2.0 & 2.75 \\
\hline L.S.D. at 5\% & 1.2 & 0.12 & 0.93 \\
\hline
\end{tabular}

At the same time, Omar (1988) investigated that ovular callus was noticed after 6 weeks on a medium containing $10 \mathrm{mg} / \mathrm{L} \mathrm{2,4-D} \mathrm{and} 2 \mathrm{mg} / \mathrm{L}$ kinetin. While, Sharon et al. (1998) mentioned that white friable callus was initiated from leaf primordia of date palm cv. Yakubi cultured on modified MS medium supplemented with $50 \mathrm{mg} / \mathrm{L} 2,4-\mathrm{D}, 1 \mathrm{mg} / \mathrm{L}$ kinetin and $0.5 \mathrm{mg} / \mathrm{L} 2 \mathrm{iP}$ and Ibrahim (1999) showed that, embryogenic callus was obtained from shoot tips and leaf primordial explants cultured on modified MS medium containing either $10 \mathrm{mg} / \mathrm{l} \mathrm{NOA}, 5 \mathrm{mg} / \mathrm{L}$ 2,4-D, $1 \mathrm{mg} / \mathrm{L}$ kinetin and $1 \mathrm{mg} / \mathrm{L} 2 \mathrm{iP}$ or $100 \mathrm{mg} / \mathrm{L}$ 2,4-D, $3 \mathrm{mg} / \mathrm{L}$ kinetin and $3 \mathrm{mg} / \mathrm{L} 2 \mathrm{iP}$.

\section{Shoot formation:}

Results in Table (3) showed that best growth vigor was in Klebsiella supernatant in the presence of tryptophan (B) that is (4) and the highest shoot was $(7 \mathrm{~cm})$ in the same treatment followed by Azotobacter supernatant with tryptophan (A), which gave growth vigor (3.5) and shoot length $(6.5 \mathrm{~cm})$. The largest number of shoot/ plant was (5) due to culturing in MS medium containing Azospirillium supernatant with tryptophan (C) these results are in agreement with those found by Kapulink et al. (1985) who found that Azospirillum has the ability to produce plant growth promoting substances such as auxins and cytokinins. El- Khawas et al. (1996) found that Azospirillum and other groups of PGPR were produce and release a broad spectra of plant growth regulators (auxins, several gibberellins and cytokinins). Garcia de Salamone et al. (2001) stated that five plant growth promoting rhizobacteria ( PGPR ) strains produced the cytokinin dihydrozeatin riboside (DHZR) in pure culture. In addition to, Saker et al. (1998) demonstrated that in in vitro tissue culture of date palm, only $2 \mathrm{iP}$ containing media was found to be satisfactory for shoot induction after a phase of callus formation. The highest percentage of shoot prolifration occured when embryos were cultured on MS medium supplemented with 3 $\mathrm{mg} / \mathrm{L}$ 2iP, $0.1 \mathrm{mg} / \mathrm{L} \mathrm{NAA}$ and $3 \mathrm{~g} / \mathrm{L}$ charcoal. 
Farrag, Hala, M.A. et al.

Table (3). Effect of bacterial supernatant added to MS medium on shoot formation of date palm (Phoenix dactylifera cv.Sewi) after 18 weeks from culturing

\begin{tabular}{|l|c|c|c|}
\hline Treatments & Growth vigor & $\begin{array}{c}\text { Shoot } \\
\text { number }\end{array}$ & Shoot length \\
\hline Azotobacter chrooccum (A) & 3.5 & 1.0 & 6.5 \\
\hline Azoto. free tryptophan (a) & 1.0 & 2.0 & 4.5 \\
\hline Klebsiella pneumoniae (B) & 4.0 & 2.0 & 7.0 \\
\hline Klebsiella free tryptophan (b) & 2.0 & 1.0 & 3.5 \\
\hline Azospirillium brasilense (C) & 2.5 & 5.0 & 5.5 \\
\hline Azosp. free tryptophan (c) & 1.5 & 2.0 & 4.0 \\
\hline Bacillus megaterium (D) & 2.5 & 3.0 & 6.0 \\
\hline Bacillus free tryptophan (d) & 3.0 & 4.0 & 4.0 \\
\hline Control & 3.0 & 3.0 & 4.5 \\
\hline L.S.D. at 5\% & 0.95 & 1.35 & 1.68 \\
\hline
\end{tabular}

Moreover Bekheet and Saker (1998) reported that in date palm micropropagation, the presence of cytokinins such as BA and 2iP in the culture media was considered as an important factor for bud differentiation. Shoot induction was confined to media containing $4 \mathrm{mg} / \mathrm{L} \mathrm{BA}, 4 \mathrm{mg} / \mathrm{L} \mathrm{2iP}$ and $0.5 \mathrm{mg} / \mathrm{L}$ NAA. Also, Zaid (2003) showed that in date palm micropropagation the culture medium supplemented with $0.5 \mathrm{mg} / \mathrm{l}$ kinetine was more effective than $0.5 \mathrm{mg} / \mathrm{l} 2 \mathrm{iP}$ on stimulating the produced shoots number and shoot length.

Rooting formation:

Results in Table (4) revealed that, significant differences were observed among treatments, while Klebsiella supernatant in the presence of tryptophan (B) gave the best growth vigor value (4), the greatest root number (6)/ plant and the tallest root $(6.5 \mathrm{~cm})$ followed by Azotobacter supernatant with tryptophan $(A)$, which recorded growth vigor value (3.5), root number (4)/ plant and root length $(5 \mathrm{~cm})$. These results and all the previous ones are in the same line with Hafeez et al. (2004) who conducted different experiments to determine the growth promotion activity of various rhizobacteria. The results showed that the root growth was depending on the ability of Azotobacter strains for IAA production.

Table (4). Effect of bacterial supernatant added to MSmedium on root formation of date palm (Phoenix dactylifera cv.Sewi) after 18 weeks form culturing

\begin{tabular}{|l|c|c|c|}
\hline Treatments & Growth vigor & Root number & Root length \\
\hline Azotobacter chrooccum (A) & 3.5 & 4.0 & 5.0 \\
\hline Azoto. free tryptophan (a) & 1.5 & 2.0 & 3.5 \\
\hline Klebsiella pneumoniae (B) & 4.0 & 6.0 & 6.5 \\
\hline Klebsiella free tryptophan (b) & 2.5 & 1.0 & 2.0 \\
\hline Azospirillium brasilense (C) & 3.5 & 3.0 & 4.0 \\
\hline Azosp. free tryptophan (c) & 3.0 & 1.0 & 2.5 \\
\hline Bacillus megaterium (D) & 1.0 & 3.0 & 4.5 \\
\hline Bacillus free tryptophan (d) & 3.0 & 1.0 & 2.0 \\
\hline
\end{tabular}




\begin{tabular}{|l|c|c|c|}
\hline Control & 3.0 & 3.0 & 4.0 \\
\hline L.S.D. at 5\% & 0.57 & 1.16 & 0.84 \\
\hline
\end{tabular}

Recently, Abd El- Kader(2007) cited that an isolate belongs to genus

Klebsiella was IAA over producers. While, (Thorpe, 1981) reported that Auxin alone and $\backslash$ or with a very low concentration of cytokinin is important for the induction of root primordial in plant tissue culture. Bekheet and Saker (1998) reported that in date palm tissue culture, rooting of proliferated shoots was achieved upon supplementation of MS culture medium with $1 \mathrm{mg} / \mathrm{L}$ NAA. Moreover, Gadalla (2003) demonstrated that in mass propagation of dry cultivars of date palm, the highest significant value of rooting percentage was observed when MS culture medium was supplemented with $3 \mathrm{mg} / \mathrm{L}$ of either NAA or IBA.

\section{REFERENCE}

Abd-El-Hamid, M .A.; M. H. A. Abou-Bakr; I. A. Ibrahim and M. A. Abd-ElBaky (2001). Some aspects of in vitro micropropagation of date palm Phoenix dactylifera L.. J. Agric. Sci. Mansoura Univ., 26 (9): 5449 5466.

Abd El-Kader, E.M. (2007). Microbial secretions and their applications in agriculture. Ph. D. Thesis, Microbiol., Dept., Fac. of Agric., Cairo Univ., Egypt.

Allen, O. M. (1959). Experiments in soil bacteriology. $1^{\text {st }}$ Ed Burgss publishing Co. Minneapolis, Minnesota. USA.

Bekheet, S. A. and M. M. Saker (1998). In vitro propagation of Egyptian date palm: $\quad$ Direct and indirect shoot proliferation from shoot tip explants of Phoenix dactylifera L. Zaghlool. The First International Conference on Date Palms, In Egypt, 150- 155.

Brackpool, A. (1988).Commercial propagation of date palm in vitro. Plant Today, May / June, 82 - 85.

Chung, K. R. and D. D. Tzeng (2004). Biosynthesis of IAA by the gallinducing fungus Ustilago esculenta. J. Biol. Sci., 4(6): 744450.

Dixon, R.A.; R. R. Eady; G. Espin; S. Hill; M. Laccarino; D. Khan and M. Merrich (1980). Analysis of regulation of Klebsiella pneumoniae nitrogen fixation (nif.) gene cluster with gene. Nature. 286:128- 132 .

Dobereiner, J. and J.M. Day(1976). Associative symbioses in tropical grasses: Characterization of microorganisms and dinitrogen fixing sites. In Proceeding of the First International Symposium on Nitrogen Fixation. Vol.2.Edited by Newton,W.E. and C.J. Nyman, Washington State, University press, Pullman, USA., pp $518-538$.

El- Khawas, H.M.; I.A. Ibrahim; H.M. Anwar and N.A. Hegazi (1996). In vitro propagation using phytohormones produced by associative diazotrophs. In : Malik K.(ed.)Abstracts, $7^{\text {th }}$ International Symposium on Nitrogen Fixation with Non-Legumes, Faisalabad, Pakistan, October 16-21, printed at:Sheikh Ghulam Ali(PVT) Ltd., Lahore, Pakistan, P 67.

Farrag, Hala M. A.(2000). Plant hormones produced by microorganisms and tissue culture applications. MsC. Thesis, Microbiology Dept., Fac. of Agric., Cairo Univ., Egypt.

Farrag Hala, , M.A., Eweda, E. E. Wedad; A.A. Guirgis;A. M. Ibrahim, A.A.El-Banna and I.A. Ibrahim(2007).Chemical and Molecular studies on some phytohormones producers bacteria(In press). 
Farrag, Hala, M.A. et al.

FAO (1984). FAO Production year Book. Food and Agriculture Organization of the United Nation, Rome, Italy.

Gadalla, E. G. (2003). Propagation of dry varietis of date palm. Ph.D. Thesis. Faculty of Agriculture, Cairo University. Egypt, pp. 109.

Garcia de Salamone, I. E. Hynes and L.M. Nelson (2001). Cytokinin production by plant growth promoting rhizobacteria and selected mutants. Can. J. Microbiol., 47:404- 411.

Gonzalez -Lopez, J.; V.Salmeron; M.V.Martinze- Toledo; F. Ballesteros and A. Ramos- Gormenzana (1986). Production of auxins, gibberellins and cytokinins by Azotobacter vinelandii ATCC 12837 in chemically defined media and dialyzed soil media. Soil Biol. Biochem., 18: 119-120.

Grayston, S.J.; J.H. Stephens and L.M. Nelson (1990). Field and green house studies on growth promoting of spring wheat inoculation with coexistent rhizobacteria. Second Int. Workshop on PGPR, Interlaken, Switzerland.88- 96. (c.f.El- Hadidy,2003).

Hafeez, F. Y.; M. E. Safdar; A. U. Chaudhry and K. A. Malik (2004). Rhizobial inoculation improves seedling emergence, nutrient uptake and growth cotton. Australian J. Exepri. Agric., 44(6): 617- 622.

Hegazi, N.A., and S.I. Niemela (1976). Note on the estimation of Azotobacter densities by membrane - filter technique. J. Appl. Bact., 41: $311-314$.

Ibrahim, A. I. (1999). Somaclonal variation during micropropagation of date palm via embryogensis. The first international conference, in Egypt, on plant tissue culture and its application. pp. $189-199$.

Joo, G.J., Y.M. Kim; I.J. Lee, K.S. Song and I.K. Rhee(2004). Growth promoting of red pepper plug seedling and the production of gibberellins by Bacillus cereus, Bacillus macroides and Bacillus pumilus. Biotechnology Letters. 26: 487- 491.

Kapulink, Y.R., R. Gafny and Y. Okon (1985). Effect of Azospirillium spp. Inoculation on root development and NO3 uptake in wheat in hydroponic systems. Can. J.Bot., 63:627- 631.

Khan, M. A.; M. S. Khalil and M. S. Al-Kahtani (1983). In vitro culture of different tissue of date palm Phoenix dactylifera L. offshoot. $1^{\text {st }}$ Symp. on date palm, King Fasial University, Al-Hassa, Saudi Arabia, pp.152157.

Mahmoud, S.A.Z.; E.M. Ramadan; F.M. Thabat and T. Khater (1984). Production of plant growth promoting substances by rhizosphere microorganisms. Zbl. Mikrobiol., 139: 227- 232.

Moursy, H. and M. Saker (1996). Date palm problems and the need for biotechnology. Abst. Of the $5^{\text {th }}$ Int. Conf. Desert. Development Texas Tech. Univ. USA, August 12-17, p.44.

Murashige, T. and F. A. Skoog (1962). A revised medium for rapid growth and biooassays with tobacco tissue cultures. Plant Physiol., 15: 473479.

One, O.; J. Van.Impe; E. Prinsen; J. Vanderleyden (2005). Growth and IAA biosynthesis of Azospirillum brasilense Sp245 is environmentally controlled. FEMS Microbiology Letters. 246(1): 125- 132.

Omar, M. S. (1988).Callus initiation, asexual embryogenesis and plant regeneration in Phoenix dactylifera L. Date Palm Journal. 6: 265-275.

Pan, M. J. and J. Van Staden (1998). The use of charcoal in in vitro culture. Plant Growth Regul., 26: 155-163.

Pottino, B. G. (1981). Methods in plant tissue culture. Dept. of Hort., Agric. College, Maryland Univ., College park, Maryland, USA., pp.8-29.

Reuveni, O. and H. L. Kipins(1974). Studies of the in vitro culture of date palm (Phoenix dactylifera L.) tissue and organs. Pamphlet, No.145, pp.3-39. 
Reynolds, J. F. and T. Murashige (1979). Asexual embryogenesis in callus culture of plants. In vitro. 15: 383-387.

Saker, M. M.; H. A. Moursy and S. A. Bekheet (1998). In vitro propagation of Egyptian date palm: morphogenic responses of immature embryos. Bulletin of Faculty of Agriculture, University of Cairo, 49 (2): 203-214.

Sharon, M.; Shankar, P. C. and Sharon, M. (1998). Somatic embryogensis and plant regeneration from leaf primordial of Phoenix dactylifera. Indian. Journal Experimental Biology, 36 (5): 426-529.

Smith, R. H. (2000). Plant tissue culture techniques and experiments. Academic Press. New York,U.S.A.,pp. 15-28.

Snedecor, G. W. and Cochoran (1972).Statistical Method 6 $6^{\text {th }}$. The lowa State Univ. Press, Ames., lowa, U.S.A., pp.593.

Thorpe, T. A. (1981).Plant tissue culture methods and application in agriculture. Academic Press, New York, U.S.A., pp. 45-60.

Tisserat, B. (1979). Propagation of date palm Phoenix dactylifera L. in vitro. Journal Experimental Botany. 30: 1275 - 83.

Tisserat,B.(1982). Factors involved in the production of plantlets from date palm callus cultures. Euphytica. 31 (1): $201-214$.

Tisserat, B. (1983). Development of new tissue culture technology to aid in cultivation and crop improvement of date palms. Proc. First Symposium on Date palm, Saudi Arabia. Pp. 126- 140.

Trigiano, R. M. and D. J. Gray (2000). Plant tissue culture concepts and laboratory exercises. CRC Press. New York, U.S.A., pp. 67.

Zaid, A. and B. Tissirat (1983). In vitro shoot tip differentiation in Phoenix dactylifera L. Date palm J., 2 (2):163-182.

Zaid, Z. E. (2003).Comparative studies on the production of date palm cultivars via tissue culture technique. Ph.D. Thesis, Pomology Dept., Fac. of Agric., Cairo Univ., Egypt.

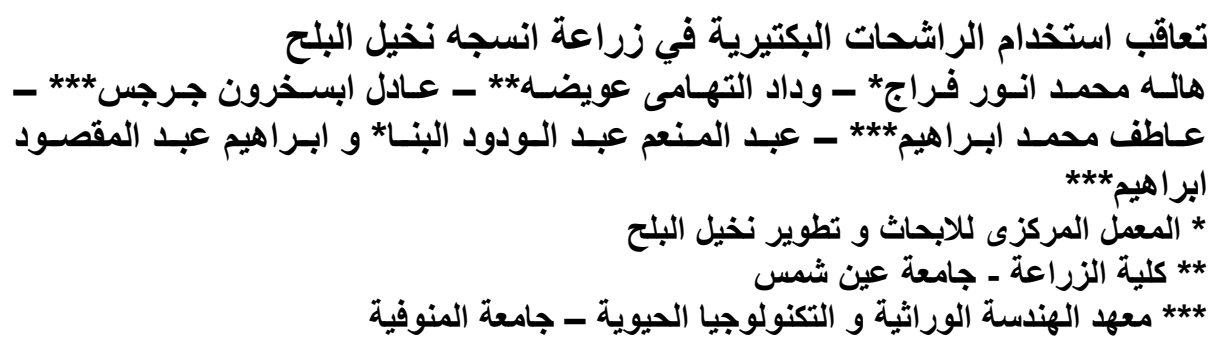

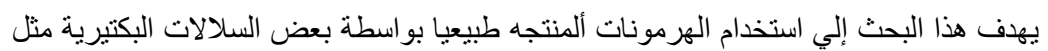

Azospirillum brasilense, Azotobacter chroococcum, Bacillus megaterium and

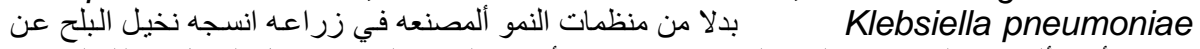

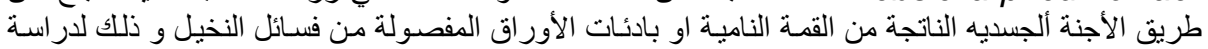

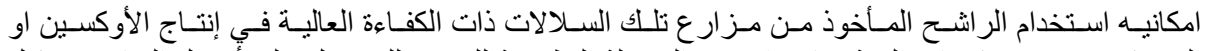

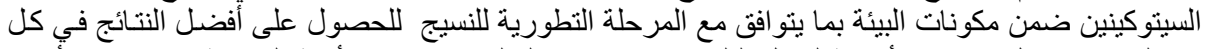

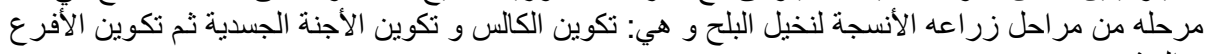
و الجذور.

بصفه عامه أظهرت النتائج أن: Klebsiella pneumoniae, Azotobacter chroococcum لها دور اوكسينى قوى بينما Bacillus megaterium, Azospirillum brasilense تنتمي في تأثير ها

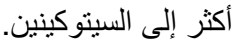


Farrag, Hala, M.A. et al.

$2195 \quad 52962197219851992200 \quad 22012202220322042205$ 